\title{
Chitosan nanoparticles containing limonene and limonene-rich essential oils: potential phytotherapy agents for the treatment of melanoma and breast cancers
}

\author{
Hiva Alipanah', Mojtaba Farjam², Elham Zarenezhad ${ }^{2,3}$, Ghazaal Roozitalab² and Mahmoud Osanloo ${ }^{4^{*}}$ (D)
}

\begin{abstract}
Background: Melanoma and breast cancers are two common cancers worldwide. Due to the side effects of chemotherapy drugs and the occurring resistance against them, the development of green drugs has been received more attention.
\end{abstract}

Methods: The anticancer effects of three essential oils from the Citrus family and their identified major constituents (limonene) were first investigated against melanoma and breast cancer cell lines (A-375 and MDA-MB-468). By preparing chitosan nanoparticles containing them, an attempt was then made to improve their effectiveness.

Results: Chitosan nanoparticles containing Citrus sinensis and Citrus limon essential oils with $\mathrm{I}_{50} \mathrm{~S}$ of 0.03 and $0.124 \mu \mathrm{g} / \mathrm{mL}$ on A-375 cells, and 23.65 and $40.32 \mu \mathrm{g} / \mathrm{mL}$ on MDA-MB-468 showed distinct anticancer efficacies.

Conclusion: The prepared formulations could thus be considered as green anticancer agents in complementary medicine and therapies.

Keywords: Citrus, Triple negative breast neoplasms, Skin neoplasms, Phytochemicals, Cytostatic agents

\section{Background}

Breast cancer is one of the most common cancer, followed by prostate, lung, and colon cancers worldwide [1]. Breast cancer is the commonest life-threatening malignancy, causing $14 \%$ of all cancer-related fatalities among women $[2,3]$. Skin cancer is another common and preventable carcinoma worldwide; its annually rising incidence has made it a pre-eminent public health threat [4]. Malignant melanoma is a type of skin cancer and responsible for the vast majority of skin cancer deaths; it begins with the abnormal proliferation of cells known as melanocytes [5]. Chemotherapy, surgery, and

\footnotetext{
* Correspondence: m.osanloo@fums.ac.ir; osanloo_mahmood@yahoo.com ${ }^{4}$ Department of Medical Nanotechnology, School of Advanced Technologies in Medicine, Fasa University of Medical Sciences, Fasa, Iran Full list of author information is available at the end of the article
}

radiotherapy are common cancer treatments, but their nonspecific action and severe side effects are cancer treatment's biggest obstacles [6, 7]. To bypass the side effects, developing new green drugs, especially essential oils (EO) $\mathrm{s}$, has recently received more attention $[8,9]$.

Citrus aurantium (bitter orange) is a tree $4-6 \mathrm{~m}$ high, evergreen, hairless, with long blades of the Rutaceae (Citrus) family [10]. It possesses antispasmodic, antiinflammatory, anti-flatulence, antihypertensive, and diuretic properties [11-13]. Citrus limon (L.) or lemon is another member of the Rutaceae family rich in vitamins, minerals, dietary fiber, and carotenoids [14]. Citrus sinensis (scientifically name for the orange) grows as a fruit-bearing shrub with green leaves and white flowers and is also a member of the Rutaceae family $[15,16]$. EOs of the three mentioned specimens possesses 
anticancer effects against different types of breast cancer cell lines. Their $\mathrm{IC}_{50} \mathrm{~s}$ against MCF-7 were reported at 82,57 , and $39 \mu \mathrm{g} / \mathrm{mL}$, their $\mathrm{IC}_{50} \mathrm{~S}$ against MDA-MB-231 were reported at 74,37 , and $39 \mu \mathrm{g} / \mathrm{mL}$, and their $\mathrm{IC}_{50} \mathrm{~S}$ against T47D were reported at $>300,19$, and $43 \mu \mathrm{g} / \mathrm{mL}$ [17]. Moreover, limonene (1-methyl-4-(1-methylethenyl) cyclohexane) is a major constituent in the mentioned EOs; it is a colorless and aromatic liquid oil and acts as a potential chemotherapeutic monocyclic monoterpene in nature [18-20]. Limonene has significant anticancer activity by inhibiting tumor initiation, growth and angiogenesis, and cancer cell apoptosis [21, 22]. For instance, the antiproliferative activity of limonene on BW5147 cells, colon, gastro, melanoma, mammary gland tumors has been confirmed [23, 24].

In this research, the anticancer effects of $C$. aurantium, C. limon, and C. sinensis EOs (CAEO, CLEO, and CSEO) and limonene were first investigated against A375 (human melanoma cancer cell line) and MDA-MB468 (human breast cancer cell line). By preparing chitosan nanoparticles (ChiNPs) containing them, an attempt was made to improve their anticancer properties.

\section{Methods}

\section{Cells and reagents}

Pasteur Institute of Iran supplied the used cell lines, including breast cancer cell line MDA-MB-468 (ATCC HTB-132) and melanoma cell line A-375 (ATCC CRL1619). Tetrazolium salt, 3-(4,5-dimethyl-thiazol-2-yl)-2, 5-diphenyltetrazo-lium bromide (MTT), phosphatebuffered saline (PBS) tablets, Sodium-tripolyphosphate (TPP), chitosan low molecular weight, acetic acid, tween 20, and limonene were purchased from Sigma-Aldrich (USA). Penicillin streptomycin, trypsin, dimethyl sulfoxide (DMSO), and Dulbecco's Modified Eagle's Media (DMEM) cell culture medium were purchased from Shellmax (China). Fetal bovine serum (FBS) was obtained from Gibco (USA). EOs were purchased from Iranian companies; CSEO Green Plants of Life Co. Ltd., CLEO Barij Essence Pharmaceutical Co., and CAEO Tabib Daru Co.

\section{Chemical composition of the EOs}

Ingredients of CSEO, CLEO, CAEO were analyzed by Gas Chromatography-Mass Spectrometry (GC-MS); the EOs were analyzed using a 6890 GC system coupled with a 5975 series of mass selective detectors (Agilent Technologies, USA). The separations were performed on HP-5MS silica fused column (length, $30 \mathrm{~m}$; internal diameter, $0.25 \mathrm{~mm}$; film thicknesses, $0.25 \mathrm{~mm}$; stationary phase, $5 \%$ phenyl $95 \%$ methyl polysiloxane). The column temperature program started at $40^{\circ} \mathrm{C}$ (fixed for $1 \mathrm{~min}$ ), then raised with a rate of $3{ }^{\circ} \mathrm{Cmin}^{-1}$ to $250{ }^{\circ} \mathrm{C}$, and was finally held for $60 \mathrm{~min}$ at this temperature. The temperature of the injection port and detector was fixed at 250 and $230{ }^{\circ} \mathrm{C}$, respectively. Other operating conditions were as follows: carrier gas, helium (99.999\%), split-flow $25 \mathrm{~mL} / \mathrm{min}$, septum purge $6 \mathrm{~mL} / \mathrm{min}$, and column flow rate $1 \mathrm{~mL} / \mathrm{min}$. Mass spectra were taken at full scan mode and $70 \mathrm{eV}$ ionization energy and full scan mode. The scanned mass range was set at $50-550 \mathrm{~m} / \mathrm{z}$. The identification of ingredients was performed as described in our previous study, and the peak area normalization procedure was used for the quantitative determination of the compounds in the EOs [25].

\section{Preparation of chitosan nanoparticles}

Chitosan powder $(0.25 \% \mathrm{w} / \mathrm{v})$ was dissolved in a $1 \%$ acetic acid aqueous solution $(4 \mathrm{~h}, 2000 \mathrm{rpm}$, ambient temperature). Preparation of chitosan nanoparticles containing limonene, CAEO, CLEO, and CSEO was obtained using a modified ionic gelation technique, as depicted in Fig. 1 [26]. Each EO or limonene $(0.5 \%$ w/v) and tween $20(0.5 \% \mathrm{w} / \mathrm{v})$ was first mixed at $2000 \mathrm{rpm}$ for $30 \mathrm{~min}$ at room temperature. The chitosan solution was then added and stirred for another $30 \mathrm{~min}$. After that, an aqueous solution of TPP $(0.15 \% \mathrm{w} / \mathrm{v})$ was added $1 \mathrm{~mL} / \mathrm{h}$ using the syringe pump, and the mixture was stirred for $40 \mathrm{~min}(2000 \mathrm{rpm})$ to stabilizing the nanoparticles. The prepared samples were abbreviated as CLChiNPs, CSChiNPs, CAChiNPs, and LimChiNPs. Moreover, the same methodology was used to prepare free chitosan nanoparticles (ChiNPs), but no EO or limonene was used.

\section{Characterization of the prepared nanoformulation Size analysis}

Dynamic light scattering (DLS) technique was used to analyze all nanoformulations particle sizes (dynamic light scattering, scatter scope, K-ONE NANO. LTD, Korea). D50 was considered particle size, and particle size distribution (SPAN) was calculated as $\mathrm{d} 90-\mathrm{d} 10 / \mathrm{d} 50$. $\mathrm{D}$ is diameter, and 10,50 , and 90 are percentile of particles with a smaller diameter than these specified diameters. Formulations with SPAN values less than 1 possess narrow particle size distributions [27].

\section{The attenuated Total reflection-Fourier transform infrared (ATR-FTIR) analysis}

ATR-FTIR has analyzed the loading of the EOs or limonene in the ChiNPs. Spectra of ChiNPs, limonene, limChiNPs, CSEO, CSChiNPs, CLEO, CLChiNPs, CAEO, and CAChiNPs were recorded in $400-4000 \mathrm{~cm}^{-1}$. The samples without preparation were subjected to the instrument (FTIR, Bruker Company, Model Tensor II, Germany). 


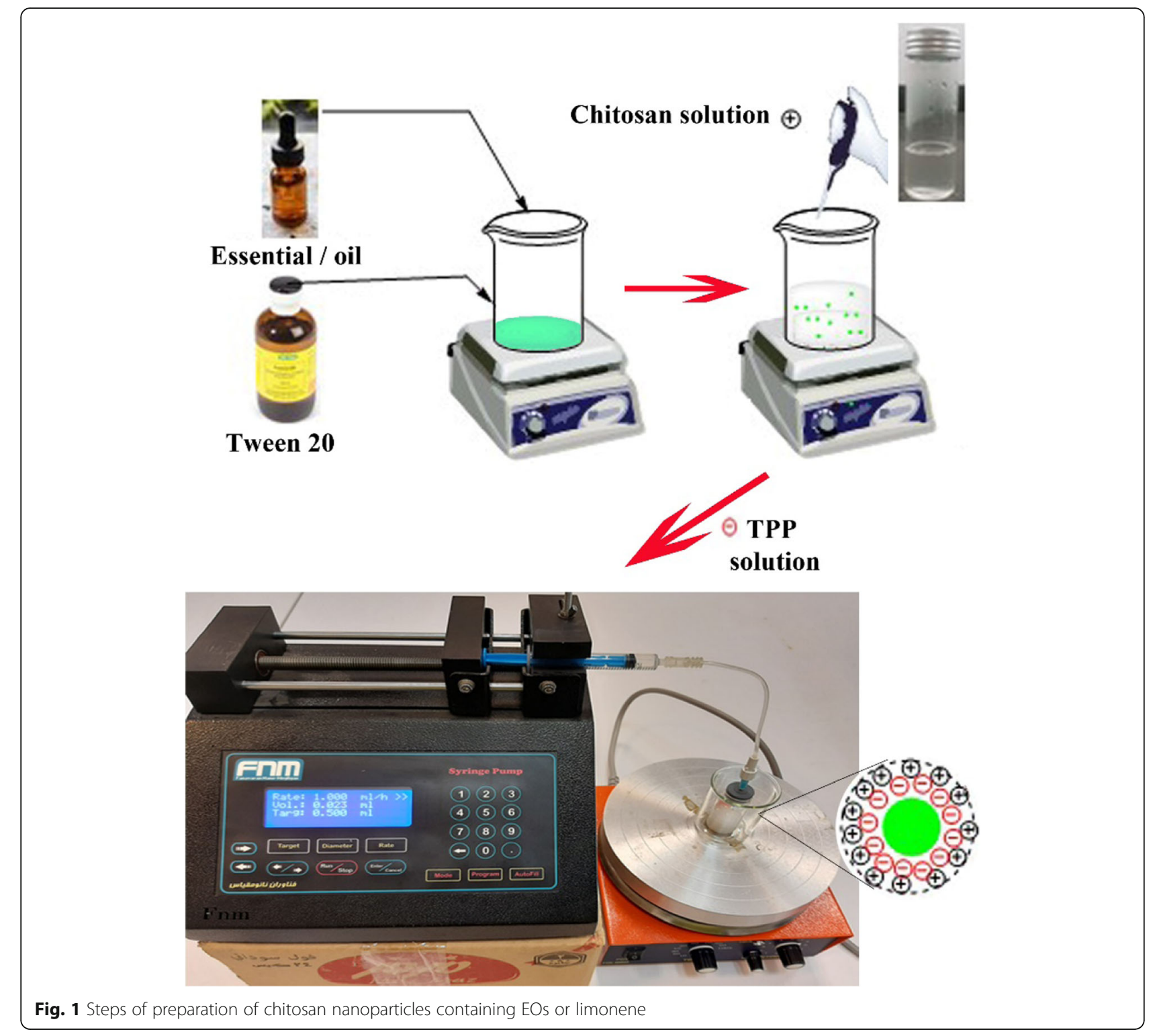

\section{Investigation of the anticancer activity}

The anticancer activity of limonene, CAEO, CLEO, and CSEO (as non-formulated samples) also, LimChiNPs, CAChiNPs, CLChiNPs, and CSChiNPs (as nanoformulations) were investigated using MTT assay. The EOs and limonene were dissolved $(0.5 \%$ $\mathrm{w} / \mathrm{v}$ ) in a PBS solution containing $0.5 \%$ DMSO. The cell lines were cultured in $75 \mathrm{~cm}^{2}$ culture flasks in DMEM medium supplemented with $10 \%$ of FBS and $1 \%$ of penicillin-streptomycin $(\mathrm{P} / \mathrm{S})$ and incubated at $37^{\circ} \mathrm{C}$ air (95\%) and $\mathrm{CO}_{2}$ (5\%). Cells (MDA-MB468 and $\mathrm{A}-375)$ were separated by trypsin; they were then seeded $\left(1 \times 10^{4}\right.$ cells per well $)$ in 96 well plates and incubated overnight for attachment. The following day, the culture media was discarded, and a $75 \mu \mathrm{L}$ complete fresh medium was added to each well. By adding an appropriate amount of the samples, concentrations were finally fixed at 1200, 600, 300,150 , and $75 \mu \mathrm{g} / \mathrm{mL}$. The treated plates were incubated for $24 \mathrm{~h}$ at $37^{\circ} \mathrm{C}$ with $\mathrm{CO}_{2} 5 \%$, and their content was then discarded, and wells were washed with $100 \mu \mathrm{L}$ PBS to remove nanoformulations milky color. After that, $100 \mu \mathrm{L}$ MTT reagent $(0.5$ $\mathrm{mg} . \mathrm{mL}^{-1}$ ) was added to each well and were incubated for another $4 \mathrm{~h}$; created formazan crystals were then dissolved by adding DMSO $(100 \mu \mathrm{L} /$ well $)$. The control group (six-well in each plate) was treated only with $25 \mu \mathrm{L}$ PBS (0.5\% DMSO) and $75 \mu \mathrm{L}$ culture media. Finally, the absorbance (A) of the wells was monitored by an ELISA plate reader at $570 \mathrm{~nm}$. The cell viability at each concentration was calculated using the following equation: 
Cell viability $(\%)=\frac{\text { Mean A sample }}{\text { Mean A control }} \times 100$

\section{Results}

\section{Identified compounds in used EOs}

Limonene was identified as the major compound in all three used EOs; it comprised $31.4 \%$ of CAEO, $61.8 \%$ of CLEO, and $71.3 \%$ of CSEO (see Table 1). Sabinene (15.6\%), $\mathrm{y}$-terpinene (6.0\%), linalool (5.6\%), and nerolidol (5.1\%) were the other four major compounds of CAEO. Alpha-pinene, sabinene, cis-limonene oxide, and translimonene oxide with a portion of 3.5, 17.0, 2.3, and 3.1\% were the other four CLEO compounds. In SCEO, transp-2,8-Menthadien-1-ol, cis-limonene oxide, trans-limonene oxide, and trans-carveol were identified as the other four major compounds (5.0, 2.6, 2.3, and 2.9\%).

The particle size of the prepared chitosan nanoparticles containing limonene or EOs

DLS analyses of the prepared nanoformulations are given in Fig. 2. CSChiNPs with a particle size of $156 \pm 8$ nm (SPAN 0.92) possess the smallest particles. CAChiNPs $(173 \pm 6 \mathrm{~nm})$, CLChiNPs $(181 \pm 4 \mathrm{~nm})$, and LimChiNPs $(209 \pm 13 \mathrm{~nm})$ were situated in other ranks; their SPAN values were including 0.94, 0.90, 0.93, respectively.

\section{Successful loading of limonene or EOs in chitosan nanoparticles}

The ATR-FTIR spectrum of ChiNPs is depicted in Fig. 3A; the bond at about $1700 \mathrm{~cm}-1$ can be related to carbonyl stretching of the pure chitosan's secondary amide band and carbonyl group tween. The characteristic peak at $1094 \mathrm{~cm}^{-1}$ relates to symmetric and antisymmetric stretching vibrations in the $\mathrm{PO}_{2}$ group, and the strong band at $1020 \mathrm{~cm}^{-1}$ belongs to symmetric and anti-symmetric stretching vibrations in the $\mathrm{PO}_{3}$ group. After the crosslinking process, two bands at 1280 and $1152 \mathrm{~cm}^{-1}$ belong to anti-symmetric stretching vibrations of $\mathrm{PO}_{2}$ groups in TPP ions. These new peaks confirmed ionic crosslinks between protonated amino groups of chitosan and tripolyphosphate anionic groups.

Table 1 Identified compounds with more than 1\% in EOs of C. aurantium, C. limon, and C. sinensis (CAEO, CLEO, and CSEO)

\begin{tabular}{|c|c|c|c|c|c|c|c|c|}
\hline \multirow[t]{2}{*}{$\mathrm{RT}^{\mathrm{a}}$} & \multirow[t]{2}{*}{$\mathrm{RI}^{\mathbf{b}}$} & \multirow[t]{2}{*}{ Compound } & \multicolumn{2}{|l|}{ CAEO } & \multicolumn{2}{|l|}{ CLEO } & \multicolumn{2}{|l|}{ CSEO } \\
\hline & & & Area & $\%$ & Area & $\%$ & Area & $\%$ \\
\hline 9.4 & 622.7 & a-pinene & $58,484,827$ & 1.7 & $126,834,642$ & 3.5 & $37,874,128$ & 1.2 \\
\hline 11.3 & 694.5 & sabinene & $542,668,432$ & 15.6 & $623,674,861$ & 17.0 & $34,246,642$ & 1.1 \\
\hline 11.3 & 696.9 & $\beta$-pinene & $43,301,938$ & 1.2 & - & - & - & - \\
\hline 12.0 & 714.9 & $\beta$-myrcene & $108,784,770$ & 3.1 & - & - & - & - \\
\hline 13.1 & 742.0 & a-terpinene & $59,177,141$ & 1.7 & - & - & - & - \\
\hline 13.9 & 762.4 & limonene & $1,088,445,097$ & 31.4 & $2,269,351,083$ & 61.8 & 2,266,978,799 & 71.3 \\
\hline 14.7 & 781.9 & $\beta$-ocimene $Y$ & $162,728,160$ & 4.7 & - & - & - & - \\
\hline 15.1 & 793.5 & $\gamma$-terpinene & $207,125,216$ & 6.0 & - & - & - & - \\
\hline 17.2 & 835.8 & linalool & $192,637,034$ & 5.6 & - & - & - & - \\
\hline 18.1 & 853.7 & cis-p-Menth-2,8-dienol & - & - & - & - & $60,702,174$ & 1.9 \\
\hline 18.6 & 864.7 & trans-p-2,8-Menthadien-1-ol & - & - & - & - & $157,669,843$ & 5.0 \\
\hline 18.8 & 868.0 & cis-limonene oxide & - & - & $83,422,623$ & 2.3 & $82,287,580$ & 2.6 \\
\hline 18.8 & 869.1 & trans-limonene oxide & - & - & $113,204,736$ & 3.1 & $72,968,453$ & 2.3 \\
\hline 20.6 & 905.3 & 4-terpineol & $66,692,764$ & 1.9 & - & - & - & - \\
\hline 21.5 & 921.1 & nortricyclene & - & - & - & - & $31,832,189$ & 1.0 \\
\hline 22.7 & 943.8 & trans-carveol & - & - & - & - & $92,456,195$ & 2.9 \\
\hline 23.2 & 953.7 & cis-carveol & - & - & - & - & $55,583,810$ & 1.7 \\
\hline 23.6 & 960.1 & cumaldehyde & $128,003,231$ & 3.7 & - & - & - & - \\
\hline 23.7 & 963.5 & carvone & - & - & - & - & $66,472,215$ & 2.1 \\
\hline 25.8 & 1002.3 & 3-buten-1-ol, 4-chloro-2-methyl-1-phenyl & $41,752,965$ & 1.2 & - & - & - & - \\
\hline 28.2 & 1047.1 & 1,2-yclohexanediol, 1-methyl-4-(1 methylethenyl) & - & - & $55,304,649$ & 1.5 & - & - \\
\hline 37.1 & 1223.5 & nerolidol & $178,234,586$ & 5.1 & - & - & - & - \\
\hline 42.9 & 1345.6 & farnesol & $34,776,356$ & 1.0 & - & - & - & - \\
\hline
\end{tabular}

${ }^{a}$ retention time, ${ }^{b}$ retention index 


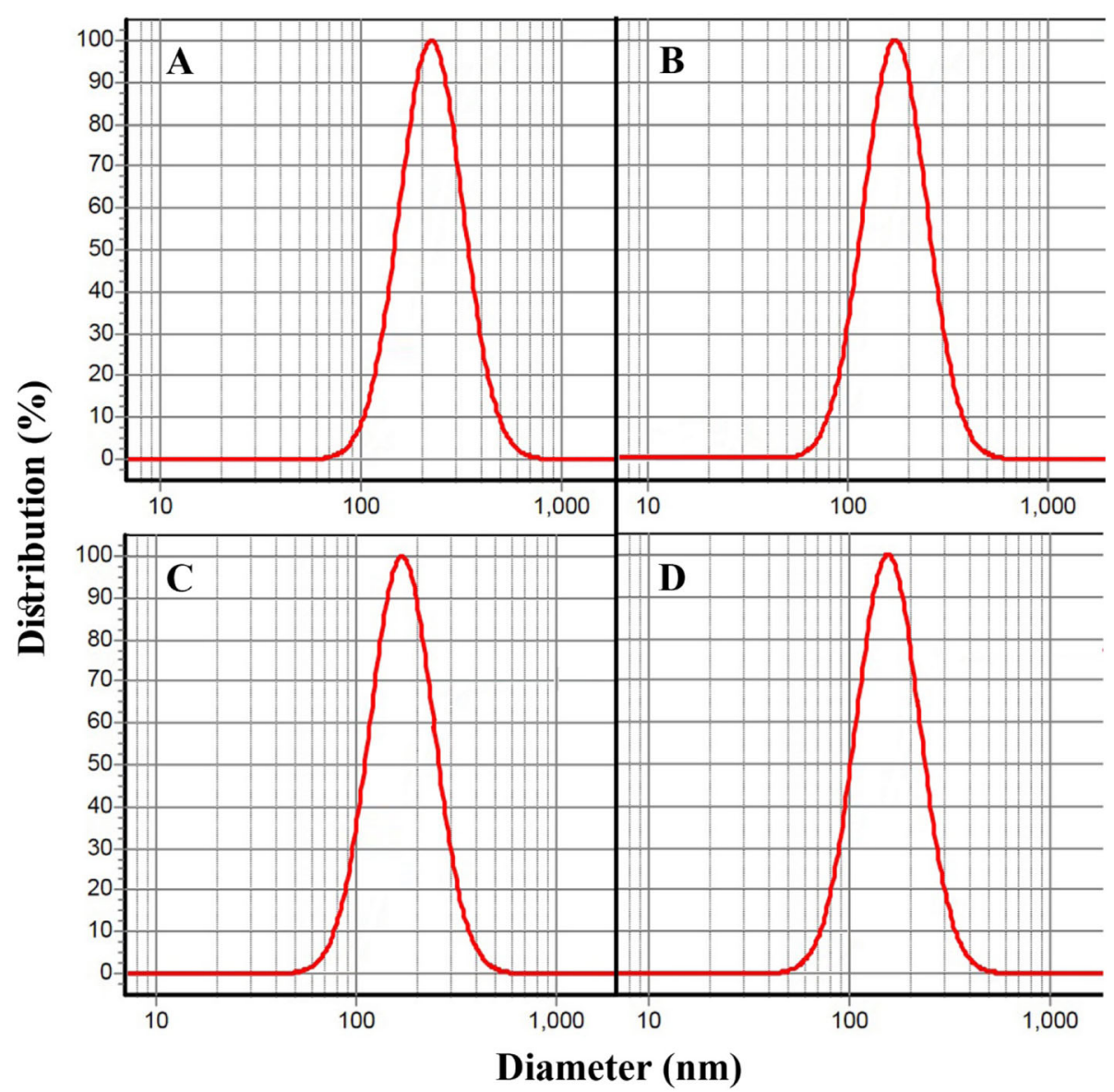

Fig. 2 Chitosan nanoparticles containing limonene and EOs of C. aurantium, C. limon, and C. sinensis: A) LimChiNPs $209 \pm 13$ nm, B) CAChiNPs $173 \pm 6 \mathrm{~nm}$, C) CLChiNPs $181 \pm 4 \mathrm{~nm}$, D) CSChiNPs $156 \pm 8 \mathrm{~nm}$

In the ATR-FTIR spectrum of limonene (Fig. 3B), the band at $3001 \mathrm{~cm}^{-1}$ relates to $=\mathrm{C}-\mathrm{H}$, and the bands at 2962, 2913, 2855, and $2855 \mathrm{~cm}^{-1}$ showed -CH stretching, the specific absorption at $1677 \mathrm{~cm}^{-1}$ corresponds to the stretching vibration of vinyl substituted $\mathrm{C}=\mathrm{C}$. The absorption band at $1644 \mathrm{~cm}^{-1}$ is assigned to the $\mathrm{C}=\mathrm{C}$ vibration. The characteristic peaks at 989 and $890 \mathrm{~cm}^{-1}$ attributed to $\mathrm{C}-\mathrm{H}$ bending absorption.

In the spectrum of LimChiNPs (Fig. 3C), the characteristic peak at $2925 \mathrm{~m}^{-1}$ is showed $\mathrm{C}-\mathrm{H}$ stretching in chitosan and $\mathrm{C}-\mathrm{H}$ of limonene. A strong characteristic peak showed at $1278 \mathrm{~cm}^{-1}$ belong to $\mathrm{C}-\mathrm{N}$ stretching indicates the complex formation via electrostatic interaction between $\mathrm{NH}^{+}$groups of chitosan within phosphoric groups of TPP. The band around $1580 \mathrm{~cm}^{-1}$ can be assigned to $\mathrm{C}-\mathrm{N}$ stretching vibration and refers to the amide group because of the $\mathrm{NH}_{2}$ bending vibration. The band at $1017 \mathrm{~cm}^{-1}$ related to $\mathrm{C}-\mathrm{O}$ in chitosan and the shape and position of the peaks proved that limonene was successfully encapsulated ChiNPs.

ATR-FTIR spectrum of CAEO is depicted in Fig. 3D; the broad peak at $3436 \mathrm{~cm}^{-1}$ attributes to $\mathrm{NH}$, the bands at 3761 related to $=\mathrm{C}-\mathrm{H}$. The bands at 2961, 2923, 2872 $\mathrm{cm}^{-1}$ displayed $-\mathrm{CH} \mathrm{cm} \mathrm{cm}^{-1}$, and the peak at $1706 \mathrm{~cm}^{-1}$ corresponding to the stretching vibration of carbonyl $\mathrm{C}=$ O. Absorption bands at 1644 and $1437 \mathrm{~cm}^{-}{ }^{1}$ are assigned to the aromatic ring $\mathrm{C}=\mathrm{C}$ skeleton vibration of an aromatic substance. The peak at $1022 \mathrm{~cm}^{-1}$ is characteristic of a stretching vibration of C-N. The peak at $957 \mathrm{~cm}^{-1}$ is attributed to $\mathrm{C}-\mathrm{H}$ bending absorption, and the strong peak at $758 \mathrm{~cm}^{-1}$ is assigned to benzene rings $\mathrm{C}-\mathrm{H}$ vibration absorption.

From Fig. 3E, some of the specific peaks of CAEO disappeared when it was encapsulated in chitosan, i.e., CAChiNPs. A strong new peak showed at $1281 \mathrm{~cm}^{-1}$ belong to the C-N stretch indicating the complex formation via electrostatic interaction between $\mathrm{NH}^{+}$groups of chitosan within phosphoric groups of TPP. Also, the band around $1547 \mathrm{~cm}^{-1} \mathrm{can}$ be assigned to $\mathrm{C}-\mathrm{N}$ stretching vibration and refers to the amide group because of the $\mathrm{NH}_{2}$ bending vibration.

In ATR-FTIR spectra of CLEO, Fig. 3F, the bands at $3399 \mathrm{~cm}^{-1}$ related to $\mathrm{OH}$ stretching vibration, the bands at $3072 \mathrm{~cm}^{-1}$ related to $=\mathrm{C}-\mathrm{H}$. The bands at 2963, 2918, 2855 , and $2834 \mathrm{~cm}^{-1}$ showed $-\mathrm{CH}$ stretching vibration, 


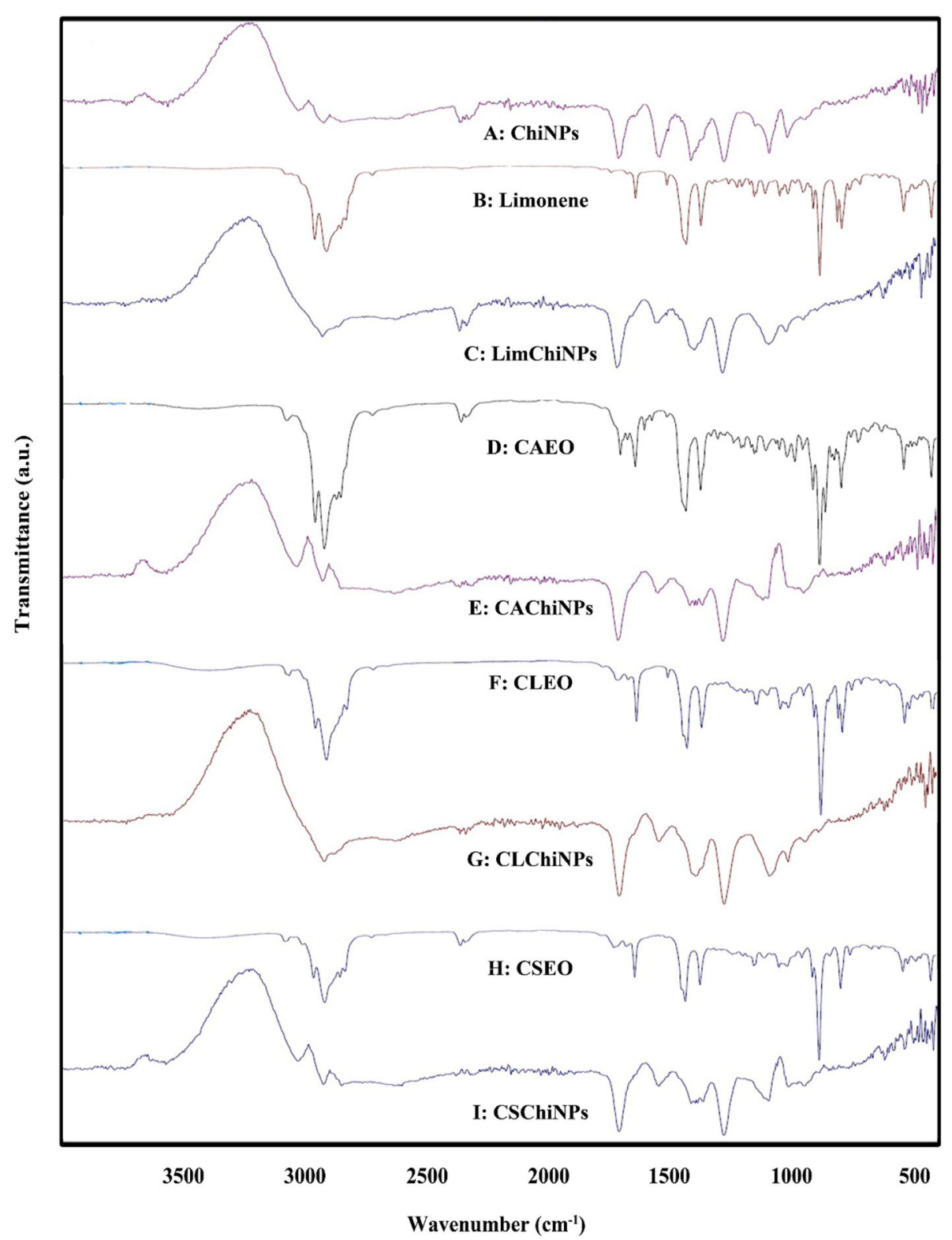

Fig. 3 ATR-FTIR of samples; A) chitosan nanoparticles, B) limonene, C) ChiNPs containing limonene, D) C. aurantium EO, E) ChiNPs C. aurantium EO, F) C. limon EO, G) ChiNPs containing C. limon EO, H) C. sinensis EO, and I) ChiNPs containing C. sinensis EO

and the characteristic bands $1677 \mathrm{~cm}^{-1}$ corresponding to $\mathrm{C}=\mathrm{C}$, the peak at around $1105 \mathrm{~cm}^{-1}$ related to $\mathrm{C}-\mathrm{O}$ bending vibration.

In ATR-FTIR of CLChiNPs (Fig. 3G), the new strong peak at around $1280 \mathrm{~cm}^{-1}$ relates to $\mathrm{C}-\mathrm{N}$ stretching was attributed to the electrostatic interaction between chitosan and TPP. Also, the sharp peak around $1545 \mathrm{~cm}^{-1}$ attributed to $\mathrm{C}-\mathrm{N}$ stretching vibration related to the amide group because of the $\mathrm{NH}_{2}$ bending vibration. All other characteristic peaks appear in the spectra of CLEO and ChiNPs; it is confirmed that CLEO was successfully encapsulated in ChNPs.
In the spectrum of CSEO (Fig. 3H), the bond at about $3412 \mathrm{~cm}^{-1}$ can be related to $\mathrm{OH}$ stretching vibrations, and the peaks at around 2964, 2918, $2885 \mathrm{~cm}^{-1}$ are related to $-\mathrm{C}-\mathrm{H}$. The vibrational bands around $1729 \mathrm{~cm}^{-1}$ related to $\mathrm{C}=\mathrm{O}$, and the band around 1677 attribute $\mathrm{C}$ $\mathrm{O}$ stretching vibrations. The main peaks around 1110, 1115 , and $1309 \mathrm{~cm}^{-1}$ are related to C-O. The peaks at $885 \mathrm{~cm}^{-1}$ attributed to $\mathrm{C}-\mathrm{H}$ bending absorption.

After CSEO was encapsulated, the spectrum showed a strong peak at $1280 \mathrm{~cm}^{-1}$ belongs to the C-N stretch, indicating the complex formation via electrostatic interaction between chitosan and TPP (see Fig. 3I). The 


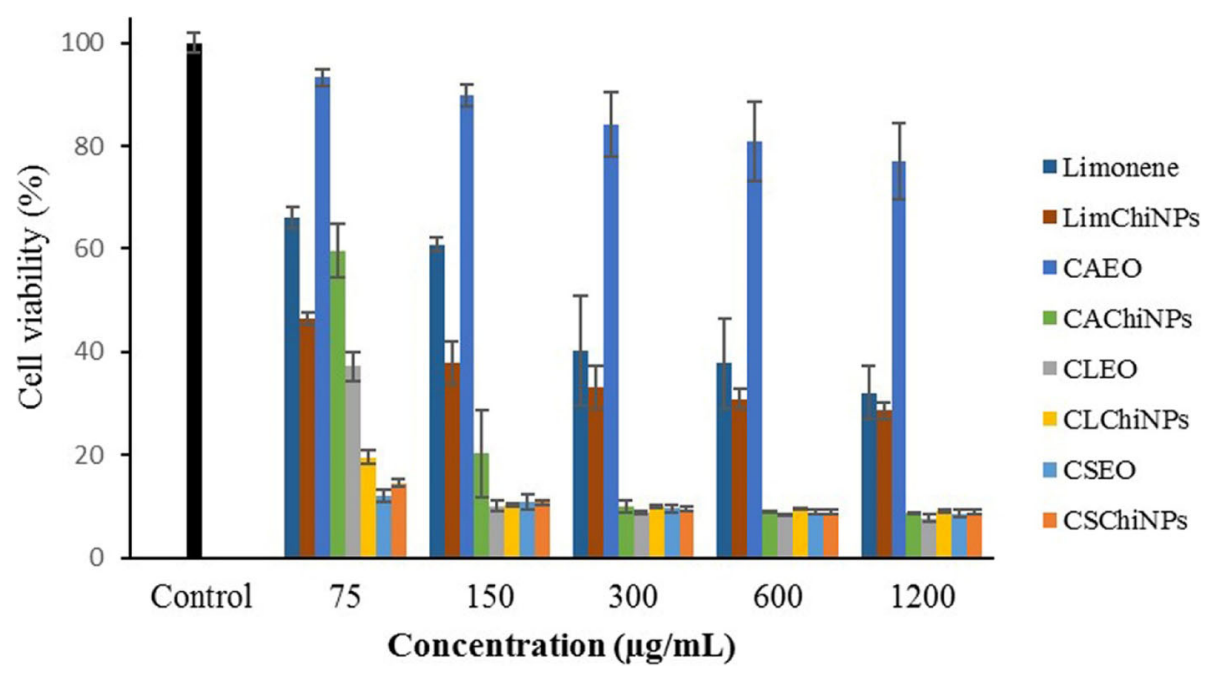

Fig. 4 Anticancer effect of limonene and EOs of C. aurantium, C. limon, and C. sinensis (CAEO, CLEO, and CSEO) and chitosan nanoparticles contained them (LimChiNPs, CAChiNPs, CLChiNPs, and CSChiNPs) against A-375 cells. Data are presented as mean \pm standard deviation $(n=3)$.

strong band around $1547 \mathrm{~cm}^{-1}$ can be assigned to C-N stretching vibration and refers to the amide group because of the $\mathrm{NH}_{2}$ bending vibration. The band at 1096 $\mathrm{cm}^{-1}$ due to the phosphoric acid root and the protonation of amino cross-linking effect.

\section{Anticancer effects of CSEO, CLEO, CAEO, and limonene}

Figure 4 illustrates the cytotoxicity effects of limonene, CAEO, CLEO, and CSEO and their nanoformulated forms on A-375 cells; obtained $\mathrm{IC}_{50} \mathrm{~s}$ are listed in Table 2. Interestingly, the viability of A-375 cells treated with CLChiNPs, CSEO, and CSChiNPs at all examined concentrations $(150,300,600$, and $1200 \mu \mathrm{g} / \mathrm{mL})$ was reduced $<20 \%$. $\mathrm{IC}_{50}$ s of CLChiNPs, CSEO, and CSChiNPs were $0.124,0.02$, and $0.03 \mu \mathrm{g} / \mathrm{mL}$. Besides, $\mathrm{IC}_{50} \mathrm{~s}$ of

Table 2 Anticancer effects of samples against A-375 and MDAMB-468

\begin{tabular}{|c|c|c|c|c|c|c|}
\hline \multirow[t]{2}{*}{ Samples } & \multicolumn{3}{|l|}{ A-375 } & \multicolumn{3}{|c|}{ MDA-MB-468 } \\
\hline & $\mathrm{LCL}^{*}$ & $\mathrm{IC}_{50}{ }^{*}$ & $\mathrm{UCL}^{*}$ & $\overline{\mathrm{LCL}}$ & $I C_{50}$ & UCL \\
\hline limonene & 176.18 & 246.05 & 343.62 & 1636.44 & 2118.94 & 2743.71 \\
\hline LimChiNPs $^{a}$ & 13.53 & 30.24 & 67.58 & 498.29 & 650.70 & 849.72 \\
\hline CAEO $^{b}$ & 4832.01 & $10,564.00$ & $23,095.00$ & 781.41 & 2037.53 & 5312.86 \\
\hline CAChiNPs $^{c}$ & 15.66 & 55.00 & 193.16 & 144.20 & 240.44 & 400.92 \\
\hline CLEO $^{d}$ & 0.49 & 10.54 & 228.46 & 57.41 & 137.03 & 327.06 \\
\hline CLChiNPs $^{e}$ & 3.270 & 0.124 & 0.05 & 10.41 & 40.32 & 156.14 \\
\hline CSEO $^{f}$ & 0.01 & 0.02 & 0.03 & 139.97 & 168.00 & 201.65 \\
\hline CSChiNPs $^{\mathrm{g}}$ & 0.02 & 0.03 & 0.05 & 2.74 & 23.65 & 204.43 \\
\hline
\end{tabular}

${ }^{\mathrm{a}}$ chitosan nanoparticles containing limonene, ${ }^{\mathrm{b}} \mathrm{C}$. aurantium EO, ${ }^{\mathrm{c}}$ chitosan nanoparticles containing $C$. aurantium EO, ${ }^{d} \mathrm{C}$. limon EO, ${ }^{\mathrm{e}}$ chitosan nanoparticles containing $C$. limon EO, ${ }^{f} \mathrm{C}$. sinensis EO, chitosan nanoparticles $C$. sinensis EO

* The half-maximal inhibitory concentration or $\mathrm{IC}_{50}(\mu \mathrm{g} / \mathrm{mL})$ with lower and upper confidence limits; LCL and UCL
LimChiNPs and CAChiNPs were observed at 30.24 and 55.00; there was no significant difference together $(p>$ $0.05)$. However, their potency was significantly more than their no-formulated forms, i.e., limonene and CAEO, with $\mathrm{IC}_{50} \mathrm{~S}$ of 246.05 and $10,564.00 \mu \mathrm{g} / \mathrm{mL}$.

From Fig. 5, the cytotoxicity effects of limonene, CAEO, CLEO, and CSEO on MDA-MB-468 cells are depicted. Generally, the samples had less potency on the growth of this cell line than A-375 cells; viability of cells reduced to lower than $10 \%$ after treating with only LimChiNPs at a concentration of $1200 \mu \mathrm{g} / \mathrm{mL}$. The bestobtained $\mathrm{IC}_{50}$ s were related to CSChiNPs $(23.65 \mu \mathrm{g} / \mathrm{mL})$ and CLChiNPs $(40.32 \mu \mathrm{g} / \mathrm{mL})$. Moreover, $\mathrm{IC}_{50} \mathrm{~s}$ of LimChiNPs and CAChiNPs (650.70 and $240.44 \mu \mathrm{g} / \mathrm{mL})$ were significantly more potent than their non-formulated forms $(2118.94$ and $2037.53 \mu \mathrm{g} / \mathrm{mL})$.

\section{Discussions}

Obtained $\mathrm{IC}_{50}$ for CSEO $(0.02 \mu \mathrm{g} / \mathrm{mL})$ against A-375 in the current study was more potent than that reported in the literature, e.g., $\mathrm{IC}_{50} \mathrm{~s}$ of Ajuga chamaepity, Sideritis montana, and Eryngium campestre EOs were reported at 67.44, 34.89, and 1.57 [28-30]. Besides, the efficacy of the most potent non-formulated sample against MDAMB-468 in the current study (i.e., CLEO $137 \mu \mathrm{g} / \mathrm{mL}$ ) was assessed as moderate compared to those published in the literature.; Kelussia odoratissima EO $85.00 \mu \mathrm{g} / \mathrm{mL}$, Zataria multiflora EO $302 \mu \mathrm{g} / \mathrm{mL}$, and Mentha piperita EO $2536 \mu \mathrm{g} / \mathrm{mL}[25,31,32]$.

Interestingly, no report was found on preparing chitosan nanoparticles containing CAEO, CLEO, CSEO, and limonene as anticancer agents on these cell lines in the literature. However, some reports on the preparation of some formulations have been found. For instance, 


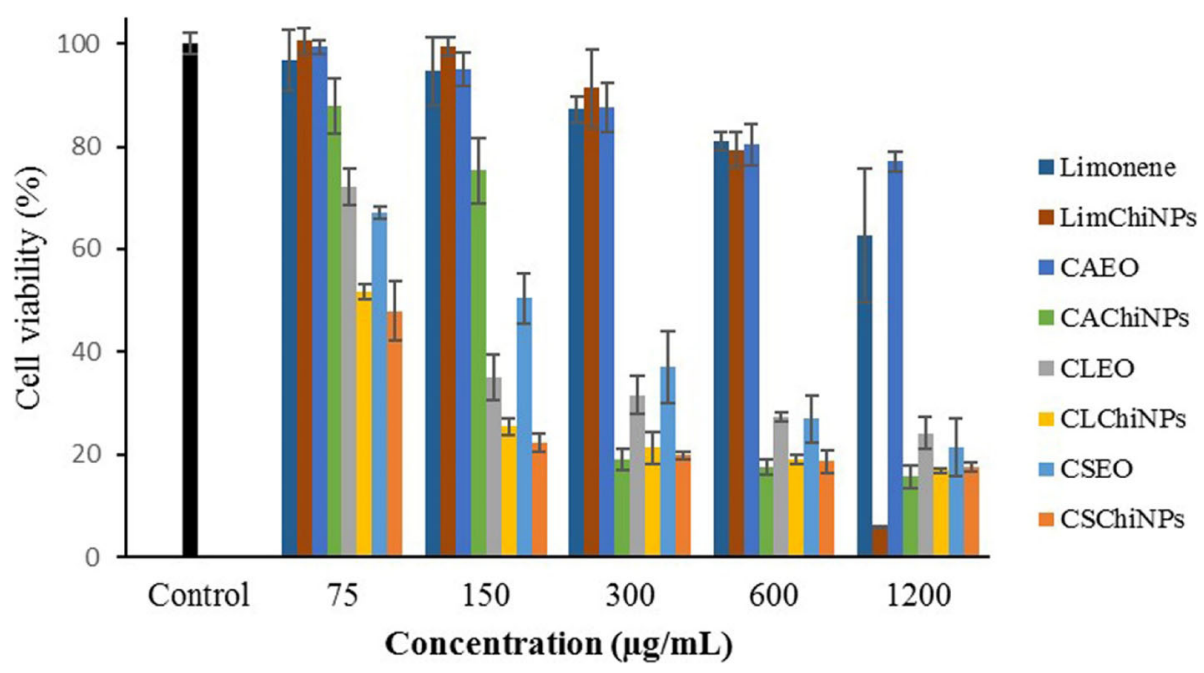

Fig. 5 Anticancer effect of limonene and EOs of C. aurantium, C. limon, and C. sinensis (CAEO, CLEO, and CSEO) and chitosan nanoparticles contained them (LimChiNPs, CAChiNPs, CLChiNPs, and CSChiNPs) against MDA-MB-468. Data are presented as mean \pm standard deviation $(n=3)$

chitosan microcapsules containing limonene with a particle size of $2-12 \mu \mathrm{m}$ were reported [33]. Electrosprayed Alyssum homolocarpum seed gum nanoparticles containing limonene with a mean diameter of $65.68 \pm 8.80$ $\mathrm{nm}$ was reported in another research [34]. In a study, CAChiNPs with a particle size of $40 \mathrm{~nm}$ was proposed as mushroom food packaging; it significantly decelerated the rate of color change, weight loss, and firmness compared to fumigation with EO [35]. In another study, by incorporating CAEO in ChiNPs $(20-60 \mathrm{~nm})$, antioxidant and antimicrobial effects were improved [36]. Chitosan nanoemulsion containing CSEO as a green fruit juice preservative was also reported [37]. In another report, CLEO was encapsulated in chitosan/hicap with a mean particle size of $339.3 \mathrm{~nm}$; it was concluded that due to the desirable physicochemical properties and thermal stability, this formulation could be used in medicine and food industries [38].

Furthermore, the preparation of nanoformulations to improve the anticancer effects of EOs has recently received much attention [39]. For instance, a study confirmed that by loading limonene into ChiNPs with a particle size of $339.5 \mathrm{~nm}$, its antioxidant became more potent by improving its solubility [40]. CAEO nanoemulsion showed cytotoxicity against A549 cells with the $\mathrm{IC}_{50}$ value of $152 \mu \mathrm{g} / \mathrm{mL}$ [41]. Besides, isolated nanovesicles from $C$. lemon have been shown an inhibitory effect in a time-dependent manner on cancer cell proliferation in different tumor cell lines by inducing apoptotic cell processes [42]. It has also been proposed that loading limonene into solid lipid nanoparticles (one of the pharmaceutical drug delivery systems) can reduce growth percentages in cancer cells with a low toxic effect on the non-tumoral cell line [43]. In vitro cytotoxicity assay showed that D-limonene-loaded niosome had a noticeable anticancer effect than D-limonene against HepG2, MCF-7, and A549 cell lines [39].

In the current study, by preparing ChiNPs containing EOs/limonene, their anticancer effects were improved, e.g., $\mathrm{IC}_{50} \mathrm{~s}$ of limonene against A-375 and MDA-MB-468 were obtained at 246 and $2118 \mu \mathrm{g} / \mathrm{mL}$, while $\mathrm{IC}_{50} \mathrm{~S}$ of its nanoformulated state (LimChiNPs) were observed at 30 and $650 \mu \mathrm{g} / \mathrm{mL}$. CAEO did not show proper efficacy on both mentioned cell lines ( $\mathrm{IC}_{50} 10,564$ and $2037 \mu \mathrm{g} / \mathrm{mL}$ ). However, after the preparation of ChiNPs containing CAEO, its $\mathrm{IC}_{50}$ s were reduced dramatically to 55 and $240 \mu \mathrm{g} / \mathrm{mL}$. Moreover, only $\mathrm{IC}_{50}$ of CSEO $(0.02 \mu \mathrm{g} / \mathrm{mL})$ against A-375 cells was not improved after preparation of its nanoformulation (CSChiNPs: $0.03 \mu \mathrm{g} / \mathrm{mL}$ ); further investigation is needed at low concentrations. However, as the hydrophobic nature of CSEO, for its practical administration in vivo or clinical trials, it should be formulated; thus, its nanoformulated form (CSChiNPs) was the best sample against A-375 cells. Interestingly, $\mathrm{IC}_{50} \mathrm{~s}$ of CSChiNPs and CLChiNPs $(0.03$ and $0.124 \mu \mathrm{g} / \mathrm{mL})$ against A-375 were more potent than cisplatin with $\mathrm{IC}_{50}$ of $0.40-0.45 \mu \mathrm{g} / \mathrm{mL}[29,44]$. Their efficacies against MDA-MB-468 (23.65 and $40.32 \mu \mathrm{g} / \mathrm{mL})$ were also comparable or more potent than cisplatin $\left(\mathrm{IC}_{50} 32.50 \mu \mathrm{g} /\right.$ $\mathrm{mL)}[45]$.

\section{Conclusions}

Compounds of three EOs from the Citrus family, including C. aurantium, C. limon, and C. sinensis, were first identified using GC-MS analysis. Their anticancer effects were then investigated on human breast cancer and melanoma cell lines. After that, chitosan nanoparticles containing EOs and limonene (as their major ingredients) 
were prepared for improving their efficacies. Chitosan nanoparticles containing Citrus sinensis and Citrus limon essential oils with $\mathrm{IC}_{50} \mathrm{~s}$ of 0.03 and $0.124 \mu \mathrm{g} / \mathrm{mL}$ on A-375 cells, and 23.65 and $40.32 \mu \mathrm{g} / \mathrm{mL}$ on MDAMB-468 showed more potency than other samples. Thus two mentioned formulations could be considered as green anticancer agents in future studies.

\section{Abbreviations}

GC-MS: Chromatography-Mass Spectrometry; ATR-FTIR: Attenuated Total Reflection-Fourier Transform InfraRed; EO: Essential Oil; CAEO: Citrus aurantium essential oil; CLEO: Citrus limon essential oil; CSEO: Citrus sinensis essential oil; ChiNPs: Chitosan nanoparticles; CAChiNPs: Chitosan nanoparticles containing Citrus aurantium essential oil; CLChiNPs: Chitosan nanoparticles containing Citrus limon essential oil; CSChiNPs: Chitosan nanoparticles containing Citrus sinensis essential oil

\section{Acknowledgments}

Not applicable.

\section{Authors' contributions}

HA performed MTT assays and was the main drafter of the manuscript. MF was the data analyzer. EZ interpreted ATR-FTIR. GhR reviewed the literature. $\mathrm{MO}$ designed the study and prepared nanoformulations. All authors contributed to drafting the manuscript and confirmed the final version. The author(s) read and approved the final manuscript.

\section{Funding}

Fasa University of Medical Sciences financially supported this research, grant number 99192.

\section{Availability of data and materials}

All data generated or analyzed during this study are included in this published article.

\section{Declarations}

Ethics approval and consent to participate

The ethical committee has ethically approved this research; IR.FUMS.REC.1399.188. This research did not involve in vivo or human study, so consent to participate did not use.

\section{Consent for publication}

Not applicable.

\section{Competing interests}

None.

\section{Author details}

'Department of Physiology, School of Medicine, Fasa University of Medical Sciences, Fasa, Iran. ${ }^{2}$ Noncommunicable Diseases Research Center, Fasa University of Medical Sciences, Fasa, Iran. ${ }^{3}$ Clinical Research Development Unit, Valie-Asr Hospital, Fasa University of Medical Sciences, Fasa, Iran. ${ }^{4}$ Department of Medical Nanotechnology, School of Advanced Technologies in Medicine, Fasa University of Medical Sciences, Fasa, Iran.

Received: 30 April 2021 Accepted: 23 June 2021

Published online: 02 July 2021

\section{References}

1. SEER Cancer Statistics Review, 1975-2018, National Cancer Institute. [https:// seer.cancer.gov/csr/1975_2018].

2. Sharma GN, Dave R, Sanadya J, Sharma P, Sharma K. Various types and management of breast cancer: an overview. J Adv Pharm Technol Res. 2010 1(2):109-26.

3. McGuire A, Brown JA, Kerin MJ. Metastatic breast cancer: the potential of miRNA for diagnosis and treatment monitoring. Cancer Metastasis Rev. 2015;34(1):145-55. https://doi.org/10.1007/s10555-015-9551-7.
4. Gordon R: Skin cancer: an overview of epidemiology and risk factors. In: Semin Oncol Nurs: 2013: Elsevier; 2013: 160-169.

5. Uong A, Zon LI. Melanocytes in development and cancer. J Cell Physiol. 2010;222(1):38-41. https://doi.org/10.1002/jcp.21935.

6. Haider T, Pandey V, Banjare N, Gupta PN, Soni V. Drug resistance in cancer: mechanisms and tackling strategies. Pharmacol Rep. 2020;72(5):1125-51. https://doi.org/10.1007/s43440-020-00138-7.

7. Blowman K, Magalhães M, Lemos M, Cabral C, Pires I. Anticancer properties of essential oils and other natural products. Evid Based Complement Alternat Med. 2018;2018:1-12. https://doi.org/10.1155/2018/3149362.

8. Pavithra PS, Mehta A, Verma RS. Essential oils: from prevention to treatment of skin cancer. Drug Discov Today. 2019;24(2):644-55. https://doi.org/10.101 6/j.drudis.2018.11.020.

9. Russo R, Corasaniti MT, Bagetta G, Morrone LA. Exploitation of cytotoxicity of some essential oils for translation in cancer therapy. Evid Based Complement Alternat Med. 2015;2015:397821.

10. Dobetsberger C, Buchbauer G. Actions of essential oils on the central nervous system: an updated review. Flavour Fragr J. 2011;26(5):300-16. https://doi.org/10.1002/ffj.2045.

11. Shen C-Y, Jiang J-G, Zhu W, Ou-Yang Q. Anti-inflammatory effect of essential oil from Citrus aurantium L. var. Amara Engl. J Agric Food Chem. 2017;65(39):8586-94. https://doi.org/10.1021/acs.jafc.7b02586.

12. Suryawanshi JAS. An overview of Citrus aurantium used in treatment of various diseases. African J Plant Sci. 2011;5(7):390-5.

13. Choi H-S, Song HS, Ukeda H, Sawamura M. Radical-scavenging activities of citrus essential oils and their components: detection using 1, 1-diphenyl-2picrylhydrazyl. J Agric Food Chem. 2000;48(9):4156-61. https://doi.org/10.1 021/jf000227d

14. González-Molina E, Domínguez-Perles R, Moreno D, García-Viquera C. Natural bioactive compounds of Citrus Limon for food and health. J Pharm Biomed Anal. 2010;51(2):327-45. https://doi.org/10.1016/j.jpba.2009.07.027.

15. Ling APK, Chia JY, Hussein S, Harun AR. Physiological responses of Citrus sinensis to gamma irradiation. World Appl Sci J. 2008;5(1):12-9.

16. Kammoun AK, Altyar AE, Gad HA. Comparative metabolic study of Citrus Sinensis leaves cultivars based on GC-MS and their cytotoxic activity. J Pharm Biomed Anal. 2021:198:113991.

17. Najar B, Shortrede JE, Pistelli L, Buhagiar J. Chemical composition and in vitro cytotoxic screening of sixteen commercial essential oils on five Cancer cell lines. Chem Biodivers. 2020;17(1):e1900478. https://doi.org/10.1 002/cbdv.201900478

18. Sun J. D-limonene: safety and clinical applications. Altern Med Rev. 2007; 12(3):259-64

19. Jia S-S, Xi G-P, Zhang M, Chen Y-B, Lei B, Dong X-S, et al. Induction of apoptosis by $\mathrm{D}$-limonene is mediated by inactivation of Akt in LS174 human colon cancer cells. Oncol Rep. 2013;29(1):349-54. https://doi.org/10.3 892/or.2012.2093.

20. Ciriminna R, Lomeli-Rodriguez M, Cara PD, Lopez-Sanchez JA, Pagliaro M. Limonene: a versatile chemical of the bioeconomy. Chem Commun. 2014 50(97):15288-96. https://doi.org/10.1039/C4CC06147K.

21. Araújo-Filho HGd, Dos Santos JF, Carvalho MT, Picot L, Fruitier-Arnaudin I, Groult H, Quintans-Júnior LJ, Quintans JS. Anticancer activity of limonene: A systematic review of target signaling pathways. Phytother Res. 2021:1-14. https://doi.org/10.1002/ptr.7125.

22. de Vasconcelos Cerqueira Braz J, de Carvalho FO, de Vasconcelos Cerqueira Meneses D, Calixto FAF, Santana HSR, Almeida IB, de Aquino LAG, de Souza Araújo AA, Serafini MR. Mechanism of Action of Limonene in Tumor Cells: A Systematic Review and Metanalysis. Curr Pharm Des. 2020. https://doi.org/1 $0.2174 / 1381612826666201026152902$

23. Manuele MG, Barreiro Arcos ML, Davicino R, Ferraro G, Cremaschi G, Anesini C. Limonene exerts antiproliferative effects and increases nitric oxide levels on a lymphoma cell line by dual mechanism of the ERK pathway: relationship with oxidative stress. Cancer Investig. 2010;28(2):135-45. https:// doi.org/10.3109/07357900903179583.

24. Mukhtar YM, Adu-Frimpong M, Xu X, Yu J. Biochemical significance of limonene and its metabolites: future prospects for designing and developing highly potent anticancer drugs. Biosci Rep. 2018:38(6): BSR20181253

25. Abedinpour N, Ghanbariasad A, Taghinezhad A, Osanloo M. Preparation of Nanoemulsions of Mentha piperita Essential Oil and Investigation of Their Cytotoxic Effect on Human Breast Cancer Lines. BioNanoScience. 2021;11: $428-36$ 
26. Osanloo M, Sedaghat M, Sereshti $H$, Rahmanian M, Saeedi Landi $F$, Amani A. Chitosan nanocapsules of tarragon essential oil with low cytotoxicity and long-lasting activity as a green nano-larvicide. J Nanostruct. 2019:9(4):723-35.

27. Abdollahi A, Mirzaei E, Amoozegar F, Moemenbellah-Fard MD, Zarenezhad E, Osanloo M. High Antibacterial Effect of Impregnated Nanofiber Mats with a Green Nanogel Against Major Human Pathogens. BioNanoScience. 2021; 11:549-58.

28. Venditti A, Frezza C, Maggi F, Lupidi G, Bramucci M, Quassinti L, et al. Phytochemistry, micromorphology and bioactivities of Ajuga chamaepitys (L) Schreb. (Lamiaceae, Ajugoideae): two new harpagide derivatives and an unusual iridoid glycosides pattern. Fitoterapia. 2016;113:35-43. https://doi.org/10.1016/j.fitote.2016.06.016.

29. Venditti A, Bianco A, Frezza C, Serafini M, Giacomello G, Giuliani C, et al. Secondary metabolites, glandular Trichomes and biological activity of Sideritis montana L. subsp. Montana from Central Italy. Chem Biodivers. 2016;13(10):1380-90. https://doi.org/10.1002/cbdv.201600082.

30. Cianfaglione K, Blomme EE, Quassinti L, Bramucci M, Lupidi G, Dall'Acqua S, Maggi F. Cytotoxic Essential Oils from Eryngium campestre and Eryngium amethystinum (Apiaceae) Growing in Central Italy. Chem Biodivers. 2017;14: e1700096.

31. Momtazi AA, Askari-Khorasgani $\mathrm{O}$, Abdollahi E, Sadeghi-Aliabadi $H$, Mortazaeinezhad F, Sahebkar A. Phytochemical analysis and cytotoxicity evaluation of Kelussia odoratissima Mozaff. J Acupunct Meridian Stud. 2017; 10(3):180-6. https://doi.org/10.1016/j.jams.2017.02.002.

32. Ghanbariasad A, Osanloo M. Development of two stable green nanoformulations with potent anticancer properties. Nanomed Res J. 2020;5(3):234-44.

33. Souza JM, Caldas AL, Tohidi SD, Molina J, Souto AP, Fangueiro R, et al. Properties and controlled release of chitosan microencapsulated limonene oil. Rev Bras Farmacogn. 2014;24(6):691-8. https://doi.org/10.1016/j.bjp.2014.11.007.

34. Khoshakhlagh K, Koocheki A, Mohebbi M, Allafchian A. Development and characterization of electrosprayed Alyssum homolocarpum seed gum nanoparticles for encapsulation of d-limonene. J Colloid Interface Sci. 2017; 490:562-75. https://doi.org/10.1016/j.jcis.2016.11.067.

35. Karimirad R, Behnamian M, Dezhsetan S, Sonnenberg A. Chitosan nanoparticles-loaded Citrus aurantium essential oil: a novel delivery system for preserving the postharvest quality of Agaricus bisporus. J Sci Food Agric. 2018;98(13):5112-9. https://doi.org/10.1002/jsfa.9050.

36. Karimirad R, Behnamian M, Dezhsetan S. Bitter orange oil incorporated into chitosan nanoparticles: preparation, characterization and their potential application on antioxidant and antimicrobial characteristics of white button mushroom. Food Hydrocoll. 2020;100:105387. https://doi.org/10.1016/j.foodhyd.2019.105387.

37. Bento R, Pagán E, Berdejo D, de Carvalho RJ, García-Embid S, Maggi F, et al. Chitosan nanoemulsions of cold-pressed orange essential oil to preserve fruit juices. Int J Food Microbiol. 2020;331:108786. https://doi.org/10.1016/j. ijfoodmicro.2020.108786.

38. Hasani S, Ojagh SM, Ghorbani M. Nanoencapsulation of lemon essential oil in chitosan-Hicap system. Part 1: study on its physical and structural characteristics. Int J Biol Macromol. 2018;115:143-51. https://doi.org/10.101 6/j.ijbiomac.2018.04.038.

39. Hajizadeh MR, Maleki H, Barani M, Fahmidehkar MA, Mahmoodi M, Torkzadeh-Mahani M. In vitro cytotoxicity assay of D-limonene niosomes: an efficient nano-carrier for enhancing solubility of plant-extracted agents. Res Pharm Sci. 2019;14(5):448-58. https://doi.org/10.4103/1735-5362.268206.

40. Li P-H, Lu W-C. Effects of storage conditions on the physical stability of dlimonene nanoemulsion. Food Hydrocoll. 2016;53:218-24. https://doi.org/1 0.1016/j.foodhyd.2015.01.031.

41. Navaei Shoorvarzi S, Shahraki F, Shafaei N, Karimi E, Oskoueian E. Citrus aurantium L bloom essential oil nanoemulsion: Synthesis, characterization, cytotoxicity, and its potential health impacts on mice. J Food Biochem. 2020;44(5):e13181.

42. Raimondo S, Naselli F, Fontana S, Monteleone F, Dico AL, Saieva L, et al. Citrus Limon-derived nanovesicles inhibit cancer cell proliferation and suppress CML xenograft growth by inducing TRAIL-mediated cell death. Oncotarget. 2015;6(23):19514-27. https://doi.org/10.18632/oncotarget.4004

43. Souto EB, Zielinska A, Souto SB, Durazzo A, Lucarini M, Santini A, et al. (+)-Limonene 1, 2-epoxide-loaded slns: Evaluation of drug release, antioxidant activity, and cytotoxicity in an HaCaT cell line. Int J Mol Sci. 2020;21(4):1449.

44. Venditti A, Bianco A, Muscolo C, Zorzetto C, Sanchez-Mateo CC, Rabanal RM, et al. Bioactive secondary metabolites from Schizogyne sericea (Asteraceae) endemic to Canary Islands. Chem Biodivers. 2016;13(7):826-36. https://doi. org/10.1002/cbdv.201500222
45. Gambini V, Tilio M, Maina EW, Andreani C, Bartolacci C, Wang J, et al. In vitro and in vivo studies of gold(I) azolate/phosphane complexes for the treatment of basal like breast cancer. Eur J Med Chem. 2018;155:418-27. https://doi.org/10.1016/j.ejmech.2018.06.002.

\section{Publisher's Note}

Springer Nature remains neutral with regard to jurisdictional claims in published maps and institutional affiliations.
Ready to submit your research? Choose BMC and benefit from:

- fast, convenient online submission

- thorough peer review by experienced researchers in your field

- rapid publication on acceptance

- support for research data, including large and complex data types

- gold Open Access which fosters wider collaboration and increased citations

- maximum visibility for your research: over $100 \mathrm{M}$ website views per year

At BMC, research is always in progress.

Learn more biomedcentral.com/submissions 